\title{
COMPARISON OF TWO-DIMENSIONAL AND THREE-DIMENSIONAL ECHOCARDIOGRAPHY IN DETERMINATION OF LEFT VENTRICLE VOLUMES AND EJECTION FRACTION IN ADULT POPULATION
}

\author{
Oliver Bushljetikj $^{1}$, Ljubica Georgievska-Ismail ${ }^{2}$ \\ ${ }^{1}$ Clinical Hospital Acibadem Sistina, Skopje, Republic of Macedonia \\ ${ }^{2}$ University Clinic of Cardiology, Skopje, Republic of Macedonia
}

Corresponding author: Oliver Bushljetikj, Clinical Hospital Acibadem Sistina, Skopje, R. Macedonia, e-mail: oliverbusljetik@yahoo.com

\section{ABSTRACT}

Introduction: Left ventricle (LV) volumes and ejection fraction (EF) determined with two-dimensional echocardiography (2DE) and three-dimensional echocardiography (3DE) show significant differences. The aim of this study is to determine the agreement of the measurements of LV volumes and EF with 2DE and $3 \mathrm{DE}$ in the general adult population, with preserved LV systolic function.

Material and methods: In 52 subjects, older than 65 years, LV end-diastolic volume index (EDVi), end-systolic volume index (ESVi) and EF were measured with 2DE and 3DE according to the official recommendations, and reproducibility of both methods and their agreement were determined.

Results: Intraclass correlation coefficient for intra-observer reproducibility in the measurement of EDVi, ESVi and EF with 2DE was $0.861,0.891$ and 0.917 respectively, whereas with $3 D E 0.854,0.893$ and 0.913 , respectively. The difference in the measurement of EDVi and ESVi was significant $(\mathrm{p}<0.001)$ whereas the measurement of EF was insignificant $(\mathrm{p}=0.153)$. The mean difference value EDVi and ESVi determined with $2 \mathrm{DE}$ and $3 \mathrm{DE}$ was $5.6+/-5.21$ and $3.01+/-2.69 \mathrm{ml} / \mathrm{m} 2$ ( $\mathrm{p}<0.001)$, and of EF $0.306+/-1.475 \%$. Spearman's correlation coefficient for EDV was 0.693, for ESV 0.763 and for EF 0.97.

Conclusion: Larger LV volumes were measured in the adult population using 3DE compared to 2DE, but identical values for EF were obtained. This difference in the measured values could not be attributed to the largeness of the LV volume and EF itself.. 3DE demonstrated better intra-observer reproducibility for $\mathrm{LV}$ volumes and $\mathrm{EF}$ as a major parameter in many clinical decisions.

Keywords: Two-dimensional echocardiography, Three-dimensional echocardiography, Left ventricle volume, Ejection fraction

\section{INTRODUCTION}

Determination of left-ventricle (LV) volumes and ejection fraction $(\mathrm{EF})$ is the most common indication for performing two-dimensional echocardiography (2DE). According to the recommendations for cardiac chamber quantification given by the European and American echocardiographic associations [1] a biplane disks summation method (modified method by Simpson) is advocated for determination of LV volumes and EF. This method has its limitations because it relies on the assumption of a fixed geometric shape of LV (bullet shape), inability to always obtain a projection along the true longitudinal LV axis which results in shortening 
of the cardiac apex, and difficulty in determination of the real endocardial border. This is particularly pronounced in various cardiac diseases that change the geometry and kinetics of some LV segments (e.g. previous myocardial infarction) [1]. All this might change the value of EF up to $7-10 \%$ between two control visits, and these differences might have impact on clinical monitoring and decision making [2].

These limitations are being overcome by using three-dimensional echocardiography (3DE), which relies on a geometrical assumption about the LV shape and there is no shortening of the longitudinal LV axis when creating the three-dimensional image. The new recommendations suggest usage of 3DE in everyday clinical practice. Reference values for these parameters determined with 3DE have been given and the same are different from those obtained with 2DE [1].

Values of LV volumes measured with 2DE and 3DE show correlation, but display significant differences compared to cardiac magnetic resonance $(\mathrm{CMR})$ as a gold standard. These is a significant heterogeneity and inconsistency among studies for the reported differences. Many studies have shown higher values of LV volumes obtained with 3DE in comparison with $2 \mathrm{DE}$, but without significant differences in the calculated EF. However, LV volumes obtained with both methods are significantly smaller than those obtained with CMR, which is regarded as the gold standard because of its high spatial resolution and ability to obtain complete volumetric data sets of $\operatorname{LV}[3,4,5,6]$.

The majority of studies about the reference values and correlation of 2DE and 3DE have been conducted in younger population, with a smaller number of patients aged over 65 years. This is the age when the LV geometry changes, hence many studies with CMP and echocardiography have observed changes in the mean value of LV volumes in this population $[7,8,9]$. With further aging, the obtained echocardiographic image is with a poorer quality that has an impact on the measured values in 2DE and 3DE [10].

The aim of this study is to determine the agreement of the measurements of LV volumes and EF with $2 \mathrm{DE}$ and $3 \mathrm{DE}$ in the general adult population older than 65 years, with preserved LV systolic function.

\section{MATERIAL AND METHODS}

The study comprised of 52 patients, over the age of 65 , who were examined for symptoms of fatigue, malaise, dyspnea, palpitation, etc. in outpatient settings. The echocardiographic examination using GE E95 with probes M5Sc (1.4-4.6 MHz) and 4V (1.5-4.0 $\mathrm{MHz}$ ) revealed that all subjects were in sinus rhythm and with preserved EF ( $>45 \%)$.

In line with the recommendations for cardiac chamber quantification (1) with 2DE, four- and twochamber views from apical position were used for determination of LV end-diastolic volume (EDV) and end-systolic volume (ESV).

$3 \mathrm{DE}$ was performed immediately after 2DE, under the same hemodynamic conditions, from apical position in four-chamber view. The recording was done over 4-6 cardiac cycles (muli-beat acquisition) in order to obtain the smallest speed of 12 images per second, when the subject had to hold his breath, most commonly in deep expiration. 3D multi-slice mode was used for LV view, with 9 short-axis slices.

The analysis was done off-line using GE EchoPAC software. In 2DE, tracing of the endocardial border/boundary was manually made. The calculation of the volumes was made with the biplane method of disk summation (modified method by Simpson), while the ejection fraction was calculated using the following formula: $E F=(E D V-$ $\mathrm{ESV}) / \mathrm{EDV}$. For each parameter, two measurements on the same image were made.

The program 4D auto LVQ was used for 3DE, which automatically traces the endocardial boundary at end-diastole and systole in line with ECG, with additional manual adjustment of the boundaries. For each parameter, two measurements on the same image were made. Papillary muscles in both recordings were included in the LV volume.

\section{Statistical analysis}

Statistical Package for Social Science program (Version 14 SPSS Inc., Chicago, Illinois, USA) was used for the statistical database.

Paired simple T test and Spearman's correlation coefficient were calculated for determination of statistical significance and correlation of the differences between the measured parameters. Values of $p<0.05$ were considered to be statistically significant.

Bland-Altman plot was made in order to present in figures the mean difference in the measured parameters - bias and limits of agreement (LOA), which includes $95 \%$ of all the differences between the two methods/measurements.

Intra-observer variabilities were determined for each parameter using Intraclass Correlation Coefficient (ICC) method. 


\section{RESULTS}

Out of 52 subjects, 23 were males (44.2\%), with mean age for both sexes of 74.25 years (from 65 to 97 years). On average, subjects had an increased body mass index (BMI) $-25.46 \pm 3.23 \mathrm{~kg} / \mathrm{m} 2$, and more than half of them $(52.6 \%)$ had BMI above $25 \mathrm{~kg} / \mathrm{m} 2$. The mean height of the subjects was $166.56 \pm 8,318 \mathrm{~cm}$. The results of the baseline and demographic examinations are presented in Table 1.

Arterial hypertension was a predominant disease, found in $76.9 \%$ of the subjects, with optimally regulated blood pressure levels of $138 \pm 15.97 \mathrm{mmHg}$ systole and $79.69 \pm 11.03 \mathrm{mmHg}$ diastole (measured in an outpatient setting). Dyslipidemia was the second most frequent $(38.5 \%)$ disease, and diabetes mellitus $(15.4 \%)$ and coronary and carotid arterial disease $(9.6 \%)$ were with smaller prevalence.

Table 1. Demographic data and characteristics of the examined population

\begin{tabular}{|l|l|}
\hline Males (n/\%) & $23(44.2)$ \\
\hline Females (n/\%) & $29(55.8)$ \\
\hline Age (years) & $74.25+/-7.172$ \\
\hline BMI (kg/m2) & $25.46+/-3.23$ \\
\hline BSA (m2) & $1.79+/-0.2$ \\
\hline Heart fr. (beats/min.) & $68.13+/-13.3$ \\
\hline Blood pressure in systole (mmHg) & $138+/-15.97$ \\
\hline $\begin{array}{l}\text { Blood pressure in diastole } \\
\text { (mmHg) }\end{array}$ & $79.69+/-11.03$ \\
\hline HTA (n/\%) & $40(76.9)$ \\
\hline Dyslipidemia (n/\%) & $20(38.5)$ \\
\hline Diabetes mellitus (n/\%) & $8(15.4)$ \\
\hline CAD/Carotids* (n/\%) & $5(9.6)$ \\
\hline
\end{tabular}

$\mathrm{BMI}=$ body mass index; $\mathrm{BSA}=$ body surface area; fr=heart frequency;

$\mathrm{HTA}=$ arterial hypertension; $\mathrm{CAD}=$ coronary arterial disease.

* Proved arteriosclerotic coronary or carotid arterial disease

EDV and ESV values were indexed to body surface area $(\mathrm{ml} / \mathrm{m} 2)$. The mean value of EDV index measured with $2 \mathrm{DE}$ was $47.05+/-8.802 \mathrm{ml} / \mathrm{m} 2$, and with 3DE $51.85+/-7.37 \mathrm{ml} / \mathrm{m} 2$. ESV index was $18.06+/-5.596 \mathrm{ml} / \mathrm{m} 2$ and $20.58+/-4.255 \mathrm{ml} / \mathrm{m} 2, \mathrm{EF}$
$62.37+/-6.228 \%$ and $61.41+/-5.496 \%$ for $2 \mathrm{DE}$ and $3 \mathrm{DE}$, respectively.

Table 2. Minimal, maximal and mean values of measured $L V$ volumes indexed to body surface area and $E F$ with $2 D E$ and $3 D E$

\begin{tabular}{|c|c|c|c|c|}
\hline & 刍 & 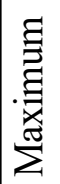 & 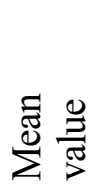 & $\theta$ \\
\hline EDVi 2DE & 30 & 75 & 46.24 & 7.779 \\
\hline EDVi 3DE & 30 & 68 & 51.85 & 7.37 \\
\hline ESVi 2DE & 10 & 40 & 17.58 & 4.683 \\
\hline ESVi 3DE & 13 & 36 & 20.58 & 4.255 \\
\hline EF biplane 2DE & 48 & 74 & 62.16 & 6.029 \\
\hline $\mathrm{EF} 3 \mathrm{DE}$ & 47 & 73 & 61.86 & 6.114 \\
\hline
\end{tabular}

EDVi - End-diastolic volume index; ESVi End-systolic volume index; 2DE - Two dimensional echocardiography; 3DE - Three dimensional echocardiography; EF - Ejection fraction

Intraclass Correlation Coefficient (ICC) for intraobserver reproducibility in the measurement of EDVi, ESVi and EF with 2DE was 0.861, 0.891 and 0.917, and with 3DE $0.854,0.893$ and 0.913 , respectively.

Table 3. Intraclass Correlation Coefficient for intra-observer variabilities in measuring $L V$ volumes and $E F$ with $2 D E$ and $3 D E$

\begin{tabular}{|c|c|c|c|}
\hline & 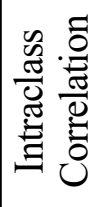 & 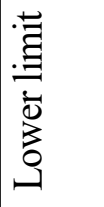 & 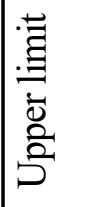 \\
\hline EDVi 2DE & 0.861 & 0.759 & 0.92 \\
\hline ESVi 2DE & 0.891 & 0.811 & 0.937 \\
\hline EF biplane 2DE & 0.917 & 0.84 & 0.955 \\
\hline EDVi 3DE & 0.854 & 0.742 & 0.917 \\
\hline EDVi 3DE & 0.893 & 0.811 & 0.94 \\
\hline $\mathrm{EF} 3 \mathrm{DE}$ & 0.913 & 0.846 & 0.951 \\
\hline
\end{tabular}

EDVi - End-diastolic volume index; ESVi End-systolic volume index; 2DE - Two dimensional echocardiography; 3DE - Three dimensional echocardiography; EF - Ejection fraction

Paired sample T-test for the differences in the measured parameters revealed a significant difference 
for EDVi and ESVi measured with 2DE compared to $3 \mathrm{DE}$, for $\mathrm{p}<0.001$, whereas there was no significant difference for the measured EF $(p=0.153)$.

Table 4. Paired sample T-test for the significance of differences for EDVi, ESVi and EF measured with $2 D E$ and $3 D E$

\begin{tabular}{|l|l|l|l|}
\hline Difference & Mean & SD & $\mathrm{P}$ \\
\hline$\Delta \mathrm{EDVi}(\mathrm{ml} / \mathrm{m} 2)$ & 5.61 & 5.31 & $<0.001$ \\
\hline$\Delta \mathrm{ESVi}(\mathrm{ml} / \mathrm{m} 2)$ & 3.01 & 2.69 & $<0.001$ \\
\hline$\Delta \mathrm{EF} \%$ & 0.306 & 1.475 & 0.153 \\
\hline
\end{tabular}

$\triangle \mathrm{EDVi}$ - mean value of difference of measured EDVi with 2DE and 3DE

$\triangle \mathrm{ESVi}$ - mean value of difference of measured ESVi with 2DE and 3DE

$\triangle E F$ - mean value of difference of measured EF with 2DE and 3DE

\section{SD - Standard Deviation}

Spearman's correlation coefficient of the measured EDVi, ESVi and EF with both methods was $0.693(p<0.001), 0.763(p<0.001)$ and 0.97 $(\mathrm{p}<0.001)$, respectively.

Table 5. Spearman's correlation coefficient (rho) of the measured $L V$ volumes and $E F$ with $2 D E$ and $3 D E$

\begin{tabular}{|l|l|l|}
\hline & $\begin{array}{l}\text { Spearman } \\
\text { (rho) coefficient }\end{array}$ & $\mathrm{P}$ \\
\hline EDVi & 0.693 & $<0.001$ \\
\hline ESVi & 0.763 & $<0.001$ \\
\hline EF & 0.97 & $<0.001$ \\
\hline
\end{tabular}

EDVi - End-diastolic volume index; ESVi End-systolic volume index; EF - Ejection fraction

In order to compare both methods for measurement Bland-Altman plot was made for each parameter. For EDVi bias +/-2SD as $95 \%$ level of agreement was $5.61+/-5.31 \mathrm{ml} / \mathrm{m} 2$, for ESVi 3.01 $+/-2.69 \mathrm{ml} / \mathrm{m} 2$ and for EF $0.306+/-1.475 \%$.

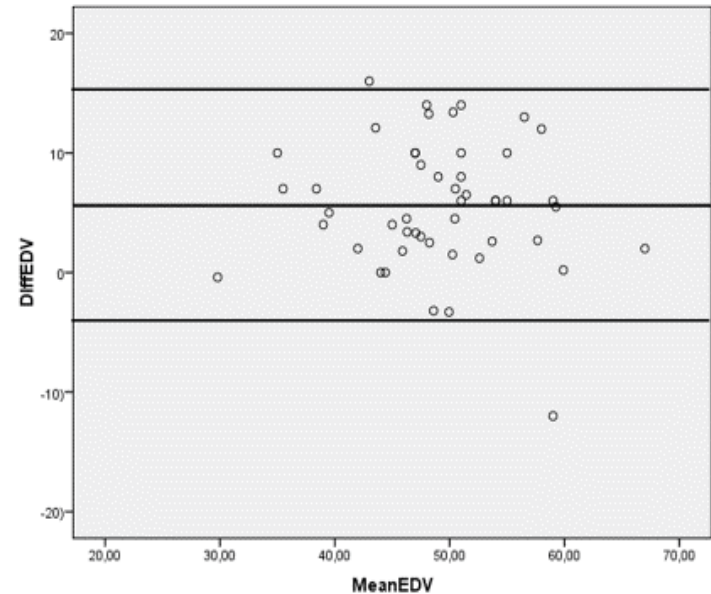

Figure 2. Bland-Altman plot presenting mean difference of measured ESVi $(\mathrm{ml} / \mathrm{m} 2)$ with $2 D E$ and $3 D E$ and $95 \%$ level of agreement

DiffESV - differences in measured ESVi with 2DE and 3DE

MeanESV - mean value of measured ESVi with $2 \mathrm{DE}$ and $3 \mathrm{DE}$

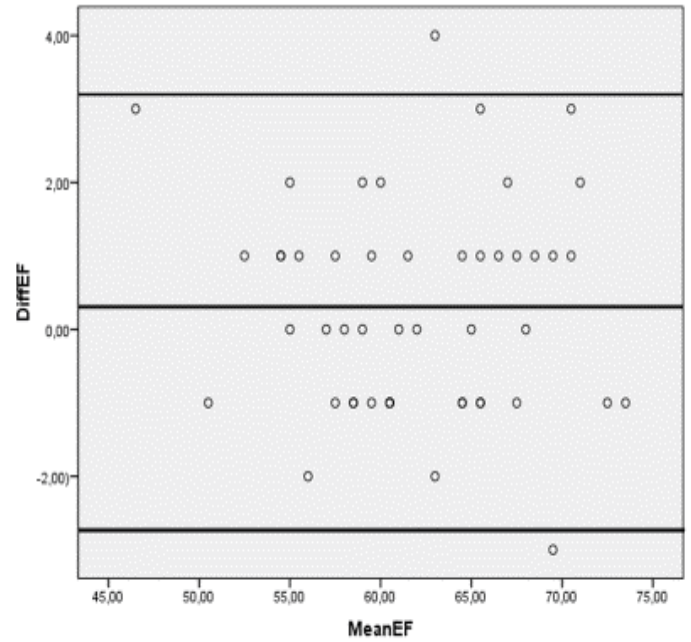

Figure 3. Bland-Altman plot presenting mean difference of measured $E F(\%)$ with $2 D E$ and $3 D E$ and $95 \%$ level of agreement

DiffEF - differences in measured EF (\%) with 2DE and 3DE

MeanEF - mean value of measured EF (\%) with $2 \mathrm{DE}$ and $3 \mathrm{DE}$ 


\section{DISCUSSION}

Our results have shown that the two techniques have good reproducibility, with a high correlation coefficient (ICC). The results obtained for 2DE are in agreement with those presented in many studies. Wood et al. in their meta-analysis of a large number of studies demonstrated that 2DE gave a good reproducibility, which was between good and excellent, with coefficients ranging from 0.80 to 0.91 for EDV, from 0.89 to 0.92 for ESV and 0.92 for EF (4).

Our results for $2 \mathrm{DE}$ have shown a good reproducibility in measuring $\mathrm{LV}$ volumes and $\mathrm{EF}$ (coefficients above 0.8 for EDV and ESV and above 0.9 for $\mathrm{EF})$.

For measurements with 3DE, the ICC demonstrated a good reproducibility for EDVi and ESVi as well as for EF. Wood et al. presented results from studies with excellent reproducibility of the method both for LV volumes and for EF. ICC coefficients were above 0.947 for EDV, above 0.982 for ESV and 0.99 for EF measured with 3DE.

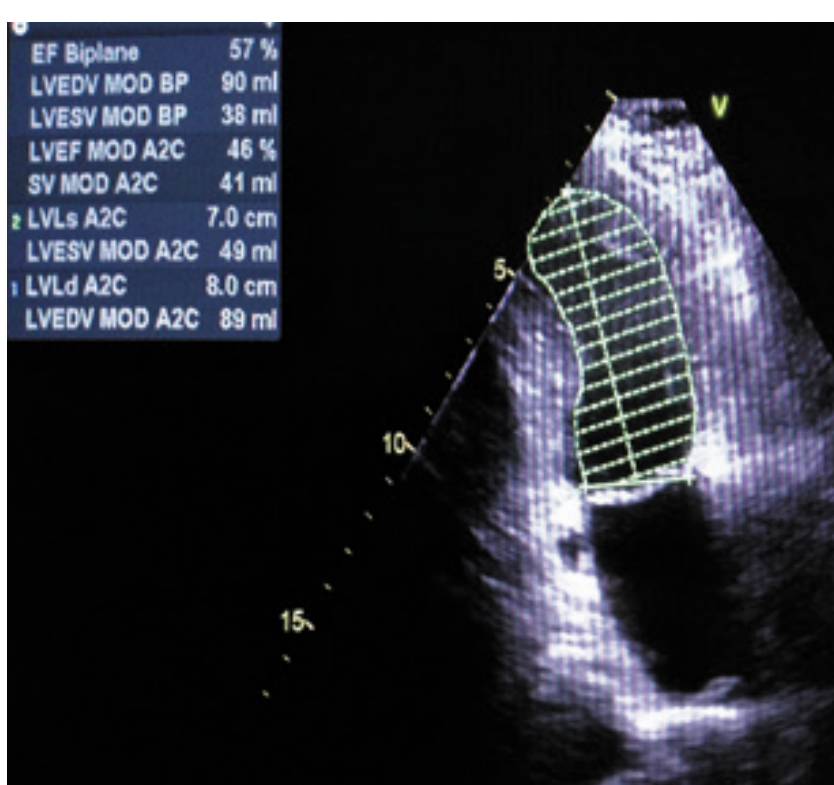

breath-hold over 4-6 consecutive cardiac cycles in order to avoid stitching of the image Also, the size of the used probe for 3DE has its influence; it has twice larger diameter than the probe for 2DE, which impedes obtaining a quality echo window in the intervertebral space and maintaining the image over 4-6 cardiac cycles. These limitations are given in the recommendations for using echocardiography in adult population with arterial hypertension [12]. All this has an impact on the quality of the image and gives explanation about the lower ICC, that is, lower reproducibility of the method in comparison with studies performed in younger population.

There are contradictory results in the literature regarding the values obtained for LV volumes with 2DE and 3DE. Some studies present significantly higher values for LV volumes with 3DE. Dorosz et al. (6) made a meta-analysis of 23 studies that compared 3DE with CMR and 2DE with CMR. For 2DE the difference (BA bias+/- 2SDs) was -48.2 +/- $55.9 \mathrm{ml},-27.7$ +/$45.7 \mathrm{ml}$ and $0.1+/-13.9 \%$ for EDV, ESV and EF, respectively. For 3DE the difference was $15.7+/-$

Picture 1. Measurement of $L V$ volumes and $E F$ with $2 D E$ and $3 D E$ at same patient

In comparison with other studies that used the same software (EchoPAC) and revealed an excellent reproducibility, our results were with lower reproducibility. 3DE has lower spatial resolution, with difficult endocardial delineation. This is particularly distinct in adult population with poor acoustic windows [10] due to higher BMI [11], higher prevalence of degenerative spinal diseases and chronic lung diseases. In adult population (our patients were with mean age over 74 years) it is more difficult to cooperate during
$31 \mathrm{ml},-9.6+/-25.8 \mathrm{ml}$ and $0.0+/-9.2 \%$, respectively. Significant differences for EDV and ESV were observed $(p=0.01)$, but not for $E F(p=0.42)$.

Nine studies performed concomitant comparison of 3DE and 2DE with CMP for determination of LV volumes and EF. In all analyzed studies, except in the study of Bicudo et al. [13], 3DE showed higher values of EDV and ESV than 2DE (mean difference $32.5 \mathrm{ml}$ and $18.1 \mathrm{ml}$ ) and closer values to those obtained with CMR. 
Meta-analysis showed no significant differences in the calculated EF with both methods.

Greupner et al. [14] in their study measured identical results of LV volumes and EF with both methods. On the other hand, Ruddox et al. [15] demonstrated even higher values of the measured volumes with $2 \mathrm{DE}$ than with $3 \mathrm{DE}$. At the same time, they found no significant difference in the EF calculated with both methods. However, almost all studies state that both methods underestimate the LV volumes compared to CMR, but without differences in the calculated EF.

Our study has revealed significantly higher values of LV volumes when measuring them with 3DE. On average, EDVi was higher for $5.6+/-5.21 \mathrm{ml} / \mathrm{m} 2$ with $3 \mathrm{DE}$ than with $2 \mathrm{DE}$, that is, higher by $11.9 \%$, and ESVi was higher for $3.01+/-2.69 \mathrm{ml} / \mathrm{m} 2$, that is, $16.66 \%$. We can explain this difference, or these higher volumes measured with 3DE by the change in the LV geometry, which receives a spherical shape along with the spherical index increase with aging.

Kaku et al. demonstrated that LV has the smallest spherical index in the 4th-5th decade. In the next life decades the index permanently increases with shortening of the long axis and LV from spherical tends to become more elliptical. Although the study of Kaku et al. [7] included a small number of patients older than 70 years, this tendency probably continues. With advancing age the HTA incidence increases, and consequently LV pressure overload that has the greatest influence on LV sphericity.

Hees et al. have presented similar results [8] by performing three-dimensional CMR in healthy population from different age groups. They have proved that LV receives a spherical shape with age, irrespective of the gender of the subjects.

In the spherical shape of LV, even a small shortening of the long axis during examination has larger negative influence in the calculation of the surface compared to the same shortening of the axis in the elliptical shape. This shortening of the longitudinal axis is one of the main disadvantages in presenting $\mathrm{LV}$ with $2 \mathrm{DE}$, with substantial importance in measuring smaller values of LV volumes. At the same time, this spherical shape of LV in the adult population does not affect the results obtained with $3 \mathrm{DE}$ where complete volumetric data of LV is shown.

The results are also influenced by moving the endocardial border deeper during manual ad- justment, by complete inclusion of trabeculae allocated to the LV chamber. The aim is to reduce LV volume underestimation compared to CMR. Mor-Avi et al. showed that moving the endocardial border for only $1 \mathrm{~mm}$ can affect the value of LV volumes by $11 \%$ [17]. This can explain the higher values of LV when using 3DE.

The two methods showed no significant difference in measuring EF. This is consistent with the results of many authors and has a huge clinical importance since EF is a leading parameter in selection and follow-up of the treatment.

The Bland-Altman figures illustrate no trends in the differences of the measured parameters with both methods, that is, the size of LV volumes and EF had no influence on the differences between the two methods.

\section{Study Limitations}

This study included patients who did not completely reflect the profile of patients from everyday clinical practice. In a large number of adult patients the LV volumes and EF cannot be determined with 3DE. According to Ruddox et al. [15] one fourth of the patients (all comers in an emergency center) who have undergone 2DE are not suitable for 3DE, mainly because of the significant prevalence of atrial fibrillation (AF) in the adult population. Phrommintikul et al. [18] reported $7.2 \%$ prevalence in the population over the age of 65 , and in those older than 80 years the corresponding rate of AF reached above $10 \%$ (Karamchalakis et al.) [19].

One of the difficulties in determination of LV volumes and EF is their constant change from one to the other cardiac cycle, depending on the hemodynamic conditions, blood pressure and heart frequency. According to Wood et al. [4] these changes in EF, for e.g., can reach up to $5.8+/-1.7 \%$. Thus, $2 \mathrm{DE}$ and $3 \mathrm{DE}$ have to be performed immediately one after another, but still these variabilities have an impact on the obtained results.

\section{CONCLUSION}

Determination of LV volumes and EF with $3 \mathrm{DE}$ in adult population can be compared and is in agreement with the values obtained with $2 \mathrm{DE}$. 
Significantly higher values of LV volumes are found, but without significant difference for EF. Largeness of LV volume or EF didn't influence the largeness of difference in measured parameters with both methods. There was no significant change in the difference of measured parameters in "bigger" LV compared to "smaller" LV. The method has a good reproducibility for LV volumes and in evaluation of $\mathrm{EF}$, which is the main parameter in many clinical decisions. These results make 3DE to be clinically applicable in everyday clinical practice in adult population, with all its specific features.

\section{REFERENCES}

1. Lang RM, Badano LP, Mor-Avi V, Afilalo J, Armstrong A, et al. Recommendations for cardiac chamber quantification by echocardiography in adults: An update from the American Society of Echocardiography and the European Association of Cardiovascular Imaging. J Am Soc Echo 2015; 28:1-39.

2. Steeds RP. Echocardiography: frontier imaging in cardiology. The British Journal of Radiology. 2011;84(Spec Iss 3):S237-S244.

3. Buccheri S, Costanzo L, Tamburino C, Monte I. Reference Values for Real Time Three-Dimensional Echocardiography-Derived Left Ventricular Volumes and Ejection Fraction: Review and Meta-Analysis of Currently Available Studies. Echocardiography. 2015;32(12):1841-50.

4. Wood PW, Choy JB, Nanda NC, Becher H. Left Ventricular Ejection Fraction and Volumes: It Depends on the Imaging Method. Echocardiography (Mount Kisco, N.y). 2014;31(1):87-100.

5. Hoffmann R, Barletta $G$, von Bardeleben $S$, Vanoverschelde JL, Kas et al. Analysis of left ventricular volumes and function: a multicenter comparison of cardiac magnetic resonance imaging, cine ventriculography, and unenhanced and contrast-enhanced two-dimensional and three-dimensional echocardiography. J Am Soc Echocardiogr. 2014 Mar;27(3):292-301

6. Dorosz JL, Lezotte DC, Weitzenkamp DA, Allen LA, Salcedo EE. Performance of 3-Dimensional Echocardiography in Measuring Left Ventricular Volumes and Ejection Fraction: A Systematic Review and Meta-Analysis. J Am Coll Cardio. 2012;59(20):1799-1808. doi:10.1016/j. jacc.2012.01.037.
7. Kaku K, Takeuchi M, Otani K, Sugeng L, Nakai $\mathrm{H}$ et al . Age- and Gender-Dependency of Left Ventricular Geometry Assessed with Real-Time Three-Dimensional Transthoracic Echocardiography. J Am Soc Echocardiogr. 2011; 24(5):541-7)

8. Hees PS, Fleg JL, Lakatta EG, Shapiro EP. Left ventricular remodeling with age in normal men versus women: novel insights using three-dimensional magnetic resonance imaging. Am J Cardiol. 2002. 1;90(11):1231-6

9. Eng J, McClelland RL, Gomes AS, et al. Adverse Left Ventricular Remodeling and Age Assessed with Cardiac MR Imaging: The Multi-Ethnic Study of Atherosclerosis. Radiology. 2016;278(3):714-722

10. Kitzman, D. W. (2000), Normal Age-Related Changes in the Heart: Relevance to Echocardiography in the Elderly. Am J Geriatric Cardiol. 9: 311-320.

11. 11. Babiarczyk B., Turbiarz A .Body Mass Index in elderly people - do the reference ranges matter? Prog Health Sci 2012, Vol 2, No1.

12. Marwick T., Gillebert T.C., Aurigemma G., Chirinos J, Derumeaux G. et al. Recommendations on the use of echocardiography in adult hypertension: a report from the European Association of Cardiovascular Imaging (EACVI) and the American Society of Echocardiography (ASE). Eur Heart J Cardiovasc Imaging 2015; 16 (6): 577-605.

13. Bicudo LS, Tsutsui JM, Shiozaki A, et al. Value of real time three-dimensional echocardiography in patients with hypertrophic cardiomyopathy: comparison with two-dimensional echocardiography and magnetic resonance imaging. Echocardiography. 2008; 25:717-26.

14. Greupner J, Zimmermann E, Grohmann A, Deubel HP, Althoff TF, Borges AC, et al. Headto-head comparison of left ventricular function assessment with 64-row computed tomography, biplane left cineventriculography, and both 2and 3-dimensional transthoracic echocardiography: comparison with magnetic resonance imaging as the reference standard. J Am Coll Cardiol 2012;59:1897-907.

15. Ruddox V, Edvardsen T, Bækkevar M, Otterstad E J. Measurements of left ventricular volumes and ejection fraction with three-dimensional echocardiography: feasibility and agreement compared to two-dimensional echocardiography Int J Cardiovasc Imaging (2014) 30:1325-1330

16. Luigi P. Badano, "The Clinical Benefits of Adding a Third Dimension to Assess the Left Ventricle with Echocardiography," Scientifica, vol. 2014, Article ID 897431, 18 pages, 2014. 
17. Mor-Avi V, Jenkins C, Kühl HP, Nesser HJ, Marwick T, et al. Real-Time 3-Dimensional Echocardiographic Quantification of Left Ventricular Volumes. JACC: Cardiovascular Imaging.2008; $1(4): 413-423$

18. Phrommintikul A, Detnuntarat P, Prasertwitayakij N, Wongcharoen W. Prevalence of atrial fibrillation in Thai elderly. J Geriatric Cardiol. 2016;13(3):270-273.

19. Karamichalakis N, Letsas KP, Vlachos K, et al. Managing atrial fibrillation in the very elderly patient: challenges and solutions. Vascular Health and Risk Management. 2015;11:555-562.

Резиме

\title{
СПОРЕДБА НА ДВОДИМЕНЗИОНАЛНАТА И ТРОДИМЕНЗИОНАЛНАТА ЕХОКАРДИОГРАФИЈА ВО ОДРЕДУВАЊЕ НА ЛЕВОКОМОРНИ ВОЛУМЕНИ И ЕЈЕКЦИОНА ФРАКЦИЈА КАЈ ВОЗРАСНА ПОПУЛАЦИЈА
}

\author{
Оливер Бушљетиќ ${ }^{1}$ Љубица Георгиевска-Исмаил ${ }^{2}$ \\ ${ }^{1}$ Клиничка Болница Аџибадем Систина, Скопје, Република Македонија \\ ${ }^{2}$ Клиника за Кардиологија, Скопје, Република Македонијаа
}

Вовед: Левокоморните (ЛК) волумени и ејекционата фракција (ЕФ), одредени со дводимензионална ехокардиографија (2ДЕ) и со тридимензионална ехокардиографија (3ДЕ), покажуваат значајни разлики.

Цел на студијата е да се одреди совпаѓањето (agreement) на мерењата на ЛК волумени и ЕФ

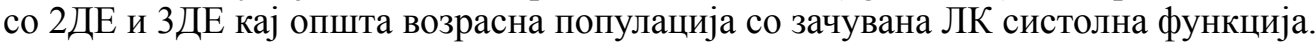

Материјал и методи: Кај 52 испитаници постари од 65 години беа измерени ЛК крајнодијастолен волумен индекс (ЕДВи), крајносистолен волумен индекс (ЕСВи) и ЕФ со 2ДЕ и ЗДЕ според официјалните препораки и беше одредена репродуцибилноста на методите и нивното совпаѓање.

Резултати: "Intraclass Correlation Coeficient" за "intra-observer" репродуцибилноста на мерењата за ЕДВи, ЕСВи и ЕФ со 2ДЕ беше 0,$861 ; 0,891$ и 0,917 , а со ЗДЕ 0,854; 0,893 и 0,913. Разликата во мерењата на ЕДВи и ЕСВи беше сигнификантна $(\mathrm{p}<0,001)$ а за ЕФ разликата беше несигнификантна

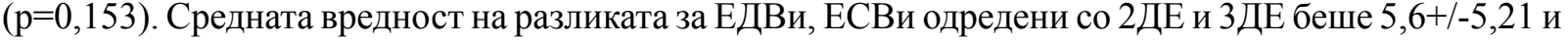
$3,01+/-2,69$ мл/м2 (p<0,001), а за ЕФ 0,306+/-1,475\%. "Spearman" коефициентот на корелација "rho" за ЕДВ беше 0,693, за ЕСВ 0,763 и 0,97 за ЕФ.

Заклучок: Со ЗДЕ, во споредба со 2ДЕ, се мерат поголеми ЛК волумени кај ворасната популација, а идентични вредности на ЕФ. Големината на волумените на ЛК и ЕФ не влијае на големината на разликата во измерените вредности. ЗДЕ покажа добра “intra-observer" репродуцибилност за ЛК волумени и за ЕФ, како главен параметар за многу клинички одлуки.

Клучни зборови: дводимензионална ехокардиографија, тридимензионална ехокардиографија, левокоморни волумени, ејекциона фракција 